dr hab. Piotr P. MAŁECKI, prof. UEK

Wydział Finansów, Uniwersytet Ekonomiczny w Krakowie

e-mail: maleckip@uek.krakow.pl

DOI: $10.15290 /$ ose.2016.02.80.01

\title{
PODATKI EKOLOGICZNE W POLSCE NA TLE INNYCH KRAJÓW UNII EUROPEJSKIEJ
}

\begin{abstract}
Streszczenie
W artykule przedstawiono wyniki analizy porównawczej w zakresie podatków związanych ze środowiskiem, obowiązujących w Polsce i w innych krajach Unii Europejskiej, które to kraje od niedawna sa zobowiązane do prowadzenia jednolitej sprawozdawczości statystycznej z tego zakresu dla potrzeb Eurostatu. Badania obejmują wielkości środków pochodzących z podatków powiązanych ze środowiskiem oraz formy „opodatkowania ekologicznego” w Polsce oraz w wybranych krajach „nowej Unii” - o podobnym poziomie rozwoju gospodarczego, jak też w wybranych krajach „starej Unii” - uważanych na ogół za przodujące w zakresie stosowania znacznego „fiskalizmu ekologicznego”. Ujęte w badaniach kraje to - obok Polski - Bułgaria, Czechy, Dania, Estonia, Finlandia, Niemcy, Rumunia, Słowacja, Szwecja oraz Norwegia (nie będąca członkiem Unii Europejskiej, lecz ujmowana w statystykach Eurostatu). Analizy dokonano badając wskaźniki określające: wielkości środków pieniężnych pochodzących z podatków ekologicznych wyrażone jako procent dochodów podatkowych ogółem oraz wielkości środków pieniężnych pochodzących z podatków ekologicznych w relacji do Unii. W artykule dokonano także analizy porównawczej konkretnych rozwiązań podatkowych w Polsce i w wybranych krajach.
\end{abstract}

Słowa kluczowe: podatki związane ze środowiskiem, sprawozdawczość statystyczna, zanieczyszczenie środowiska, Polska, Unia Europejska

\section{ECOLOGICAL TAXES IN POLAND AND OTHER EUROPEAN UNION COUNTRIES}

\section{Summary}

This paper presents the results of a comparative analysis of environmentally related taxes existing in Poland and other EU countries which have recently become obliged to introduce a uniform statistical reporting system in this field for the needs of Eurostat. The research examines the quantity of revenues from environmental taxes and the forms of 'ecological taxation' in Poland and selected New Union countries with similar levels of economic development, as well as in some of the countries of the Old Union, generally considered leaders in 'ecological fiscalism'. Apart from Poland, the authors take into account the following countries: Bulgaria, Czech Republic, Denmark, Estonia, Germany, Romania, Slovakia, Finland, Sweden, and Norway (which although does not belong to EU, is included in the Eurostat statistics). The analysis consists in investigating the indicators that reflect the amount of monetary resources from ecological taxes expressed as a share of total revenue from taxes as well as the amount of 
monetary resources from ecological taxes relative to GDP. Moreover, a comparative analysis of specific tax solutions in Poland and selected countries is conducted.

Key words: environmentally related taxes, statistical reporting, environmental pollution, Poland, European Union

JEL: G23

\section{Wstęp}

Podatki ekologiczne, a właściwie - w świetle nazewnictwa stosowanego obecnie przez Eurostat - podatki zwiazane ze środowiskiem to jeden z podstawowych instrumentów ekonomicznych służących realizacji polityki ochrony środowiska przez państwo. Liczba i rodzaje takich podatków oraz formy opodatkowania różnią się w poszczególnych krajach Unii Europejskiej. W celu stworzenia w miarę jednolitej sprawozdawczości dotyczącej podatków związanych ze środowiskiem, Unia Europejska nałożyła na państwa członkowskie obowiązek sporządzania takich rachunków. W ramach prac przygotowawczych do wypełnienia tego obowiązku kraje Unii Europejskiej, w tym Polska, opracowały obszerne zestawienia dotyczące wielkości i rodzajów podatków ekologicznych w nich obowiązujących. Stanowią one znakomity materiał badawczy służący analizie komparatywnej w tym zakresie.

Głównym celem niniejszego artykułu jest przedstawienie wyników przeprowadzonej analizy porównawczej w zakresie podatków związanych ze środowiskiem, które obowiązuja w Polsce i w innych państwach Unii Europejskiej. Obejmuje to porównanie wielkości środków pochodzących z podatków powiązanych ze środowiskiem oraz form „opodatkowania ekologicznego" w Polsce i wybranych krajach tzw. nowej Unii o podobnym poziomie rozwoju gospodarczego, jak też w wybranych krajach „starej Unii”” uważanych na ogół za przodujące w zakresie prowadzenia skutecznej polityki proekologicznej i stosowania znacznego „fiskalizmu ekologicznego”.

\section{Pojęcie podatku ekologicznego w ujęciu Eurostatu}

W opracowaniach Eurostatu, jak też innych instytucji międzynarodowych (np. OECD) w odniesieniu do podatków - nazywanych najczęściej w literaturze naukowej - ekologicznymi, dominuje ostatnio sformułowanie ,podatki związane (powiązane, odnoszące się do) ze środowiskiem" (ang. environmentally related taxes) ${ }^{1}$.Jest to efektem pewnych przemyśleń i modyfikacji w zakresie interpretacji tych proekologicznych instrumentów finansowych. Najogólniej rzecz ujmując, według nowych interpretacji, przyjmuje się tylko jedną kategorię, a co za tym idzie - także jedną nazwę w stosunku do wszelkich obciążeń finansowych ponoszonych przez podmioty gospodarcze i inne organizacje oraz przez gospodarstwa domowe, które to obciążenia mają związek ze środowiskiem.

${ }^{1} \mathrm{~W}$ artykule zamiennie będzie także używać się bardziej znanego i częściej stosowanego w literaturze określenia „podatek ekologiczny”. 
Dotyczy to więc nie tylko podatków, ale także innych obciążeń tego typu, a więc głównie opłat, jak również narzutów, należności, odpisów itp. ${ }^{2} \mathrm{~W}$ istocie rzeczy chodzi o szeroko rozumiane podatki (i opłaty) ekologiczne (czy też środowiskowe), nazywane teraz jednolicie - „podatkami związanymi ze środowiskiem”.

Zatem zgodnie z tą najnowszą interpretacją, za podatek ekologiczny (określony jak „podatek związany ze środowiskiem”) uważa się taki podatek, dla którego bazą opodatkowania jest jednostka fizyczna (lub substytut jednostki fizycznej) „czegoś”, co ma udowodniony, specyficzny, negatywny wpływ na środowisko. Zarazem, co jest dosyć istotne, podatek ten jednocześnie musi być uznawany za podatek w ESA [Environmental taxes..., 2013, s. 9] $]^{3}$, czyli musi to być obowiązkowe i bezzwrotne obciążenie finansowe w gotówce lub w innej formie nakładane przez instytucje rządowe i samorządowe albo przez inne instytucje Unii Europejskiej. Równocześnie za „coś, wyrażone w jednostce fizycznej, co ma niekorzystny wpływ na środowisko, uznaje się zjawisko, działanie lub rzecz, które oddziałuje w negatywny sposób na środowisko naturalne. Może to być na przykład: emisja do powietrza kilograma dwutlenku siarki, pobór metra sześciennego wody powierzchniowej czy też sztuka torby plastikowej na zakupy.

Opisaną definicję podatku związanego ze środowiskiem uważa się za obowiązująca dla krajów członkowskich Unii Europejskiej w zakresie obowiązów sprawozdawczych na potrzeby Eurostatu. Zawarta jest ona w art. 3 Rosporzadzenia Parlamentu Europejskiego $i$ Rady w sprawie europejskich rachunków ekonomicznych środowiska [Rozporzadzenie Parlamentu Europejskiego..., 2011], które to rozporządzenie nakłada na kraje członkowskie obowiązek w zakresie sporządzania rachunków podatków związanych ze środowiskiem i przekazywania danych sprawozdawczych do Komisji Europejskiej (Eurostatu). Jednocześnie w myśl tego rozporządzenia podatki powiązane ze środowiskiem sa przyporządkowywane do jednej z czterech grup rodzajowych, tj.:

1. energia,

2. transport,

3. zanieczyszczenie środowiska,

4. zasoby naturalne.

Niekiedy grupy rodzajowe „zanieczyszczenie środowiska” oraz „zasoby naturalne” są ujmowane jako jedna całość. Często ma to miejsce w przedmiotowych raportach instytucji międzynarodowych.

Zaliczenie danego podatku do odpowiedniej grupy rodzajowej zasadniczo jest podyktowane jego podstawa (baza) opodatkowania. Jednakże w niektórych przypadkach nie jest to jednoznaczne. Na przykład akcyza na samochody może być zaliczona do grupy „transport”, ale także do grupy „zanieczyszczenia środowiska”, gdyż eksploatacja samochodów powoduje zarówno zanieczyszczenie w postaci emisji do powietrza, jak i hałas. Wobec takiej niejednorodnej kategorii podatku należy zastosować „zasadę większościową". Sformułowanie to nie jest jednak precyzyjne i wymaga weryfikacji, a ostateczną decyzję podejmuje urząd statystyczny danego kraju. Ponadto, w tym względzie

${ }^{2} \mathrm{~W}$ raportach wspomnianych instytucji międzynarodowych występują takie anglojęzyczne sformułowania, jak: fees, charges, levies itp.

${ }^{3}$ Jest to System Rachunków Narodowych zalecany przez Unię Europejską (ang. European System of Accounts). 
obowiązują również pewne reguły ogólne. W szczególności podatki nakładane na paliwa przeznaczane do celów transportowych zawsze są zaliczane do grupy „energia” [Małecki, w druku].

\section{Analiza porównawcza wielkości środków pochodzących z podatków ekologicznych w Polsce i w wybranych krajach Unii Europejskiej}

Rozmiary opodatkowania ekologicznego w poszczególnych państwach Unii Europejskiej są różne. Jest to uzależnione od wielu czynników, m.in. takich jak: wielkości i poziomy rozwoju gospodarczego poszczególnych krajów, zróżnicowanie systemów ekonomiczno-prawnych, różne priorytety rozwojowe czy poziom świadomości ekologicznej oraz skłonność do płacenia podatków w ogóle. Stąd też dokonywanie porównań w tym zakresie na podstawie wielkości nominalnej jest w niewielkim stopniu uzasadnione, a w pełni obiektywna ocena porównawcza jest trudna czy wręcz niemożliwa do przeprowadzenia. Bardziej miarodajne zatem wydaje się wykorzystywanie miar względnych. W raportach instytucji międzynarodowych i opracowaniach naukowych najczęściej używa się do tego celu wskaźników obrazujących:

- $\quad$ wielkości środków pieniężnych pochodzących z podatków ekologicznych wyrażonych jako procent dochodów podatkowych ogółem;

- $\quad$ wielkości środków pieniężnych pochodzących z podatków ekologicznych w relacji do PKB.

Niekiedy, choć rzadziej, stosuje się wskaźnik obrazujący wielkości środków pieniężnych pochodzących z podatków ekologicznych przypadających na głowę mieszkańca.

Celem porównań międzynarodowych wykorzystuje się także strukturę rozmiarów opodatkowania ekologicznego według wydzielonych grup rodzajowych, takich jak: energia, transport, zanieczyszczenie środowiska, zasoby naturalne. Przy czym najczęściej dwie ostatnie $z$ wymienionych grup są łączone w jedną.

W tabeli 1. pokazano wskaźniki ilustrujące wielkości środków pieniężnych pochodzących z podatków ekologicznych, wyrażonych jako procent dochodów podatkowych ogółem oraz w relacji do PKB. Wskaźniki obejmują dwa dość odległe lata, tj.: 2007 i 2013, co umożliwia dokonanie porównań związanych ze zmiennością badanych zjawisk (w tabeli - wskaźniki dynamiki). Zgodnie z przyjętym założeniem, zaprezentowane dane dotyczą obok Polski, również wybranych krajów tzw. nowej Unii (w tym przypadku: Bułgarii, Czech, Estonii, Rumunii, Słowacji), jak również wybranych krajów „starej Unii” (tj.: Danii, Finlandii, Niemiec, Norwegii ${ }^{4}$ i Szwecji).

\footnotetext{
${ }^{4}$ Norwegia nie jest członkiem Unii Europejskiej, ale jest uwzględniana w raportach Eurostatu.
} 


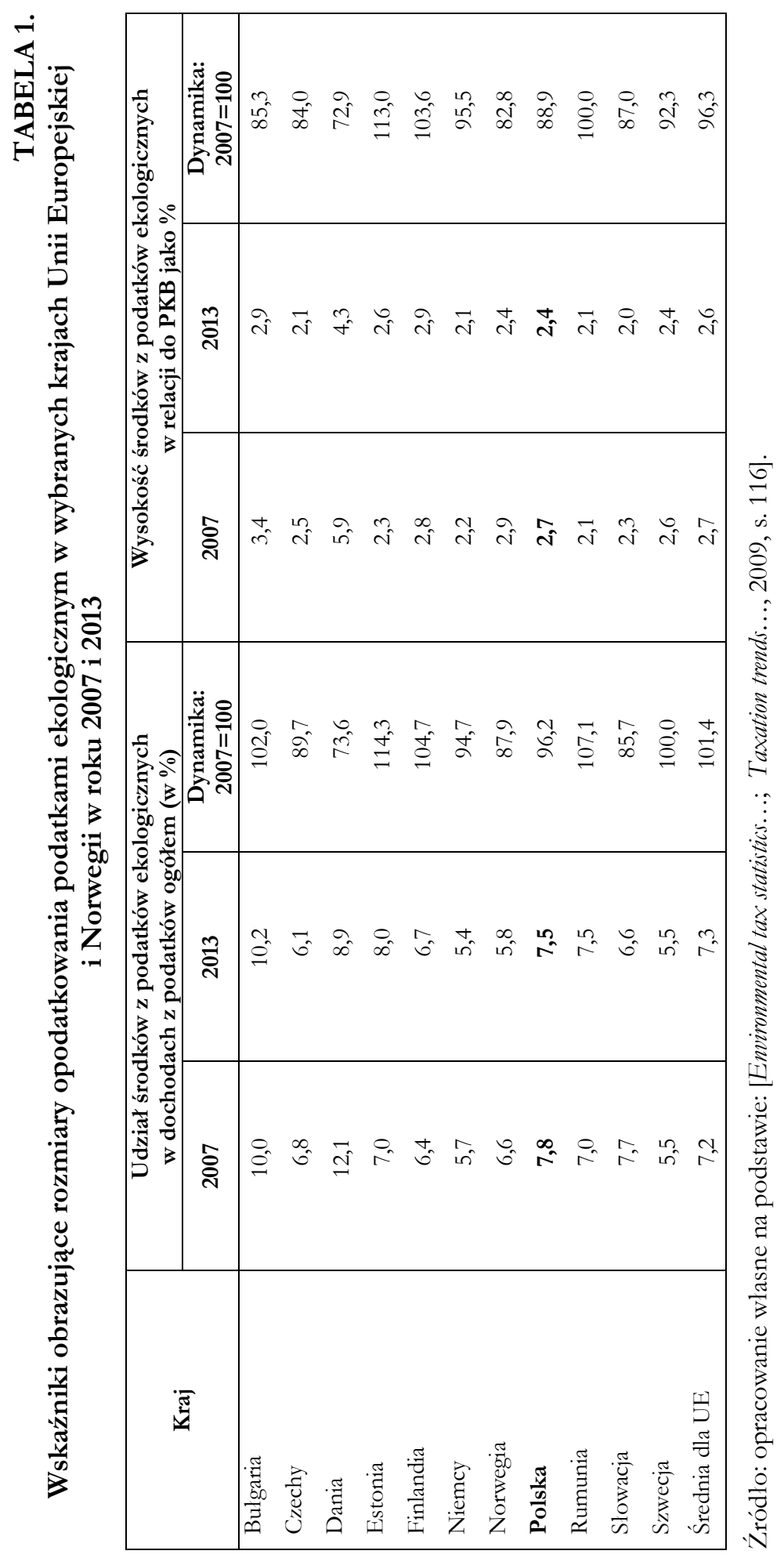


Analizując wskaźniki obrazujące udział środków pochodzących z podatków ekologicznych w dochodach z podatków ogółem w poszczególnych, wybranych krajach (tabela 1.), można dostrzec następujące prawidłowości. W zakresie porównań pomiędzy dwiema grupami krajów przyjętymi do analiz występuja pewne różnice, co dotyczy zarówno 2007, jak i 2013 roku. Przede wszystkim, co bardzo symptomatyczne, stosunek wielkości środków pieniężnych pochodzących z podatków ekologicznych do dochodów podatkowych ogółem jest w nowych krajach członkowskich przeciętnie wyższy niż w państwach „starej Unii”. Zatem średnia wielkość wskaźnika wyrażającego udział środków z podatków ekologicznych w dochodach z podatków ogółem dla analizowanych w artykule krajów „starej Unii” wynosiła w roku 2007 i 2013 odpowiednio: 7,3\% i 6,5\%, podczas gdy dla państw ,,nowej Unii” dla obu lat było to 7,7\%. Najwyższe wskaźniki występują w przypadku Danii i Bułgarii, z tym że w pierwszym z wymienionych państw wyraźnie nastąpiło obniżenie wskaźnika z 2007 w stosunku do 2013 roku. Także w większości z analizowanych krajów udział środków pochodzących z podatków ekologicznych w dochodach z podatków ogółem zmalał między rokiem 2007 a 2013. W Polsce pozostawał on jednak na prawie niezmienionym poziomie. Był również bliski średniej unijnej, która dla 2013 roku wynosiła 7,3\%.

W przypadku drugiego z analizowanych wskaźników - relacja wysokości środków pochodzących z podatków ekologicznych do PKB - zauważone wcześniej prawidłowości nieco zmieniają swój obraz. Analizowane w tym artykule kraje „starej Unii” charakteryzują się bowiem na ogół nieco wyższymi wskaźnikami. Średnia ich wielkości wynosiła w latach 2007 i 2013 odpowiednio: 3,3\% i 2,8\%, a dla państw „nowej Unii” - 2,6\% i 2,3\%. W szczególności odnosi się to do Danii, który to kraj ma wyraźnie najwyższą relację udziału środków z podatków związanych ze środowiskiem do PKB w obu badanych latach. W analizowanych krajach jednocześnie można zauważyć na ogół spadek tego wskaźnika między latami 2007 a 2013. Dotyczy to zarazem Polski. Przy tym relacja wysokości środków z podatków ekologicznych do PKB w Polsce była nieco niższa od średniej unijnej, wynoszącej w 2013 roku 2,6\%.

Jak już nadmieniono, zgodnie z odpowiednim rozporządzeniem Parlamentu Europejskiego i Rady, podatki powiązane ze środowiskiem są przyporządkowywane do określonych grup rodzajowych. Na rysunku 1. pokazano strukturę wielkości środków pochodzących z podatków ekologicznych w badanych krajach w 2013 roku, według trzech grup rodzajowych, tj.: energia, transport oraz łącznie - zanieczyszczenie środowiska i zasoby naturalne. Wyraźnie widać, iż w krajach „starej Unii” występuje większe obciążenie podatkowe grupy „transport”. W szczególności dotyczy to Norwegii i Danii. Z kolei w krajach „nowej Unii” (z wyjątkiem Czech i Rumunii) można zaobserwować relatywnie duże obciążenie podatkami ekologicznymi zaliczanymi do grupy „zanieczyszczenie środowiska i zasoby naturalne". Wynika to z faktu, że w większości tych krajów funkcjonują - podobnie jak w Polsce - liczne opłaty za korzystanie z zasobów i emisję do środowiska, z których środki są przekazywane nie do budżetu, lecz do instytucji finansujących ochronę środowiska. Zaprezentowana na rysunku 1. struktura wielkości środków z podatków ekologicznych nie uległa zasadniczej zmianie w porównaniu z 2007 rokiem, poza jednym wyjątkiem. W Danii w tymże roku wielkości środków pochodzących z podatków ekologicznych, przypadających na poszczególne grupy rodzajowe, były w miarę zbliżone [Małecki, 2012, s. 82]. 


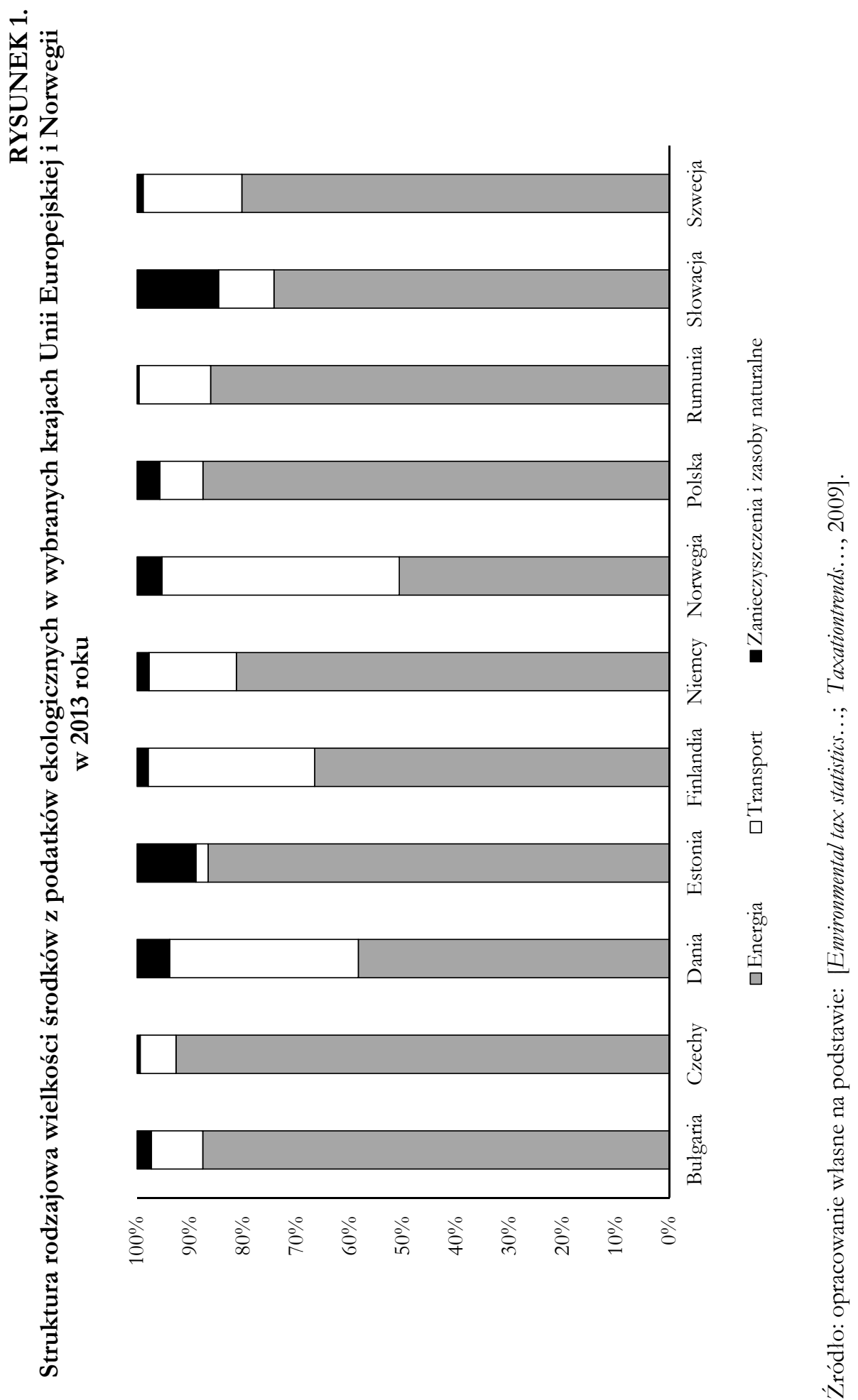




\section{Analiza porównawcza w zakresie form opodatkowania ekologicznego w Polsce oraz w Danii, Estonii i Rumunii}

Z zakresu podatków powiązanych ze środowiskiem do porównań z rozwiązaniami polskimi wybrano trzy kraje, tj. Danię - ze względu na stosowany przez ten kraj znaczny „fiskalizm ekologiczny” oraz Estonię i Rumunię - ze względu na podobny do Polski poziom rozwoju gospodarczego. Zdecydowano się na analizę tych państw także z uwagi na najbardziej aktualne (lata 2012 i 2013) raporty z badanej dziedziny sporządzane na potrzeby sprawozdawczości unijnej ${ }^{5}$. Zaprezentowana większość rozwiązań w tych krajach została ujęta w podziale na grupy rodzajowe (energia, transport, zanieczyszczenie środowiska, zasoby naturalne).

Zagregowaną listę podatków związanych ze środowiskiem obowiązujących w Polsce, przyjęta przez GUS do celów sprawozdawczych, pokazano w tabeli $2^{6}$. Lista ta została wypracowana na podstawie dotychczasowych badań naukowych, jak również opracowań oraz interpretacji Eurostatu.

Jak wynika z wcześniejszych zapisów, Dania charakteryzuje się znacznym „fiskalizmem ekologicznym". Przekłada się to na dużą liczbę różnych form opodatkowania. W związku z tym, w grupie rodzajowej „energia” obowiązuja: podatki od emisji $\mathrm{CO}_{2}$ (,węglowy”) oraz $\mathrm{SO}_{2}$ (,siarkowy”), podatek od energii elektrycznej, podatki od paliw (benzyna, oleje napędowe, opałowe i pochodne, węgiel i pochodne, gaz ziemny). W zakresie podatków transportowych obowiązują:

- podatek od masy samochodu (płacony przez gospodarstwa domowe),

- podatek od masy samochodu (płacony przez firmy),

- podatek rejestracyjny (samochody, samoloty),

- podatek od opon,

- podatek od ubezpieczenia odpowiedzialności cywilnej posiadaczy pojazdów samochodowych,

- podatek od liczby pasażerów (samoloty, samochody),

- opłata drogowa,

- opłata recyklingowa,

- podatek od dużych jachtów,

- podatek od ubezpieczenia łodzi rekreacyjnych.

W Danii występuje znaczna liczba podatków „polucyjnych” (zaliczanych do grupy „zanieczyszczenie środowiska”). Mają one charakter opłat produktowych. Ważniejsze, wybrane przedmioty opodatkowania to:

- żarówki i bezpieczniki,

- naczynia jednorazowe,

- odpady (niesegregowane),

- $\quad$ torby plastikowe, papierowe itp.,

- baterie niklowo-kadmowe i akumulatory,

${ }^{5}$ Sa to: [Introduction of NACE..., 2012; Air Emissions..., 2013; Environmental Accounts..., 2013].

${ }^{6}$ Szczegółową listę, dotyczącą wszystkich tytułów opodatkowania z tego zakresu, zawiera literatura naukowa, głównie: [Bartniczak, Ptak, 2011; Małecki, 2012]. 
- rozpuszczalniki zawierające chlor,

- folia PCV,

- nawozy fosforowe.

TABELA 2.

Lista obowiązujących w Polsce podatków związanych ze środowiskiem przyjęta przez GUS na potrzeby sprawozdawczości Eurostatu

\begin{tabular}{|c|c|}
\hline Podatek związany ze środowiskiem & $\begin{array}{l}\text { Przyporządkowanie } \\
\text { do grupy rodzajowej }\end{array}$ \\
\hline Akcyza na paliwa przeznaczone do celów opałowych lub napędowych & \multirow{5}{*}{ Energia } \\
\hline Akcyza na gaz LPG & \\
\hline Akcyza na energię elektryczną & \\
\hline $\begin{array}{l}\text { Opłaty celne na importowane: paliwa mineralne, oleje mineralne i produkty ich } \\
\text { destylacji, substancje bitumiczne, woski mineralne }\end{array}$ & \\
\hline Opłaty zastępcze za niewykupienie wymaganej ilości energii odnawialnej & \\
\hline Akcyza na samochody osobowe & \multirow{6}{*}{ Transport } \\
\hline $\begin{array}{l}\text { Opłaty celne na importowane: pojazdy, statki powietrzne, jednostki pływające } \\
\text { oraz współdziałające urządzenia transportowe }\end{array}$ & \\
\hline Opłaty rejestracyjne i ewidencyjne pojazdów & \\
\hline Podatek od środków transportowych & \\
\hline Opłaty za brak sieci zbierania wyeksploatowanych pojazdów & \\
\hline Opłata paliwowa & \\
\hline Akcyza na oleje smarowe & \multirow{9}{*}{$\begin{array}{l}\text { Zanieczyszczenie } \\
\text { środowiska }\end{array}$} \\
\hline Opłaty za odprowadzanie ścieków & \\
\hline Opłaty za emisję gazów i pyłów & \\
\hline Opłaty produktowe za opakowania & \\
\hline Opłaty produktowe za oleje smarowe & \\
\hline Opłaty produktowe za opony & \\
\hline Opłaty produktowe za baterie i akumulatory & \\
\hline Opłaty za zużyty sprzęt elektryczny i elektroniczny & \\
\hline Opłaty za substancje zubożające warstwę ozonową & \\
\hline Opłaty za pobór wód & \multirow{2}{*}{ Zasoby naturalne } \\
\hline Opłaty za usuwanie drzew i krzewów & \\
\hline
\end{tabular}

Źródło: opracowanie własne na podstawie: [Europejskie rachunki..., 2013, s. 19-20]. 
W zakresie podatków zaliczonych do grupy „zasoby naturalne” obowiązują podatki od: wydobycia i importu surowców, poboru wody, ropociagów, substancji ropopochodnych oraz podatek korporacyjny płacony przez rafinerie.

W Danii przeważaja podatki ekologiczne. Natomiast w Polsce wyraźnie dominuja opłaty tego typu.

Kolejny kraj, przyjęty do przedstawionej w tym artykule analizy porównawczej, to Estonia. Stosowane rozwiązania systemowe z zakresu opodatkowania ekologicznego są tu porównywalne z polskimi, także $z$ tego powodu, że środki z niektórych podatków/opłat ekologicznych są przekazywane do Centrum Inwestycji Ekologicznych czyli odpowiednika Narodowego Funduszu Ochrony Środowiska i Gospodarki Wodnej - z przeznaczeniem na działania na rzecz ochrony środowiska. Jednakże liczba rodzajów podatków powiązanych ze środowiskiem jest mniejsza, jakkolwiek kraj ten charakteryzuje się relatywnie dużym „fiskalizmem ekologicznym” (tabela 1.).

W dziedzinie podatków energetycznych obowiązuje tylko akcyza od: benzyn, oleju napędowego, gazu LPG itp., paliw stałych (węgiel, koks itp.), gazu ziemnego, innych paliw do napędu silników (paliwa niekonwencjonalne, olej roślinny, różne płynne substancje palne) oraz energii elektrycznej. Natomiast w zakresie podatków transportowych występuja jedynie: podatek od samochodów ciężarowych oraz opłata rejestracyjna od samochodów. W odniesieniu do podatków powiązanych ze środowiskiem zaliczanych do grupy ,zanieczyszczenie środowiska” stosuje się, analogicznie jak w Polsce, różne opłaty: od zanieczyszczenia powietrza (m.in.: $\mathrm{SO}_{2}, \mathrm{CO}, \mathrm{CO}_{2}$, metale ciężkie itd.), od zanieczyszczenia wód (substancje organiczne, komponenty fosforowe i azotowe, zawiesiny itd.), za składowanie odpadów oraz, co charakterystyczne, podatek akcyzowy od opakowań. W Polsce i wielu innych krajach opakowania są obciążone opłatami produktowymi. W zakresie podatków zasobowych w Estonii występują typowe opłaty za pobór wód i oryginalne opłaty od rybołówstwa.

W Rumunii, podobnie jak w Polsce i Estonii, część środków z podatków związanych ze środowiskiem jest kierowana do specjalnej instytucji - Narodowej Agencji Ochrony Środowiska - z przeznaczeniem na finansowanie działań ochronnych. Poza tym, kraj ten charakteryzuje się dosyć dużą liczbą rozwiązań podatkowych z badanej dziedziny, ale wskaźniki pokazujące rozmiary opodatkowania ekologicznego są nieco niższe w Estonii i w Polsce (tabela 1.). W zwiazku z tym, w grupie rodzajowej „energia” obowiązują: opłata celna od importowanych produktów energetycznych, akcyza od sprzedaży produktów energetycznych i od sprzedaży energii elektrycznej. Oryginalnym rozwiązaniem jest specjalny podatek rozwojowy obciążający taryfy za energię elektryczną i cieplna.

Znaczna liczba podatków powiązanych ze środowiskiem dotyczy transportu. Są to:

- akcyza od importu samochodów osobowych,

- akcyza od sprzedaży samochodów osobowych produkowanych w kraju,

- opłata ryczałtowa za użytkowanie dróg publicznych,

- podatek od środków transportu (płacony przez osoby prawne),

- podatek od środków transportu (płacony przez osoby fizyczne),

- podatek od pierwszej rejestracji pojazdu silnikowego,

- $\quad$ specjalny podatek od importu samochodów. 
Dosyć oryginalnymi rozwiązaniami są: opłata ryczałtowa za użytkowanie dróg oraz podatek od importu samochodów (o pojemności silnika od $2000 \mathrm{~cm}^{3}$ ).

W Rumunii obowiązuje dosyć duża liczba podatków „polucyjnych”. Poniższa lista zawiera jedynie te, z których środki są znaczne bądź też, które stanowią nietypowe rozwiązania. Są to zatem:

- akcyza od importu urządzeń klimatyzacyjnych,

- podatek od działalności niebezpiecznych dla zdrowia,

- opłaty za emisję z pojazdów spalinowych,

- opłaty za emisję do powietrza z działalności przemysłowej,

- opłata opakowaniowa,

- $\quad$ ekopodatek od toreb na zakupy z materiałów nieodnawialnych? ${ }^{7}$.

Warto dodać, że podatek od działalności niebezpiecznych dla zdrowia (produkcja, użycie, przechowywanie itd.) obejmuje również reklamy tego typu działalności.

W dziedzinie podatków zaliczonych do grupy ,zasoby naturalne” obowiązują takie rozwiązania, jak: podatek od ropy naftowej i gazu ziemnego, podatek od poszukiwania i wydobywania kopalin, odpis od wartości sprzedaży drewna (na potrzeby przemysłu).

Większość z podatków związanych ze środowiskiem (czy to w formie podatków, czy opłat) obowiązujących w Polsce występuje także w: Danii, Estonii i Rumunii. Niektóre z nich dotyczą tego samego przedmiotu opodatkowania, na przykład: paliw, energii elektrycznej, samochodów, opakowań. W niektórych z tych krajów funkcjonuja, podobnie jak w Polsce, specjalne instytucje gromadzace środki z opłat ekologicznych z przeznaczeniem na działania ochronne. Niekiedy są realizowane pewne, oryginalne rozwiązania podatkowe. Na przykład w Estonii obowiązują opłaty od rybołówstwa, a w Rumunii - specjalny podatek od importu samochodów czy ekopodatek od toreb na zakupy z materiałów nieodnawialnych.

Pewne proekologiczne rozwiazzania podatkowe stosowane w Polsce, takie jak np.: opłaty za składowanie odpadów, opłaty za działalność górnicza (koncesyjne i eksploatacyjne) bądź odpis od wartości sprzedaży drewna, nie znalazły się na liście podatków związanych ze środowiskiem przyjętej przez GUS na potrzeby sprawozdawczości Eurostatu. Tymczasem występują one w sprawozdawczości niektórych porównywanych krajów.

W Danii, w przeciwieństwie do Polski i dwóch innych porównywanych krajów, dominują podatki ekologiczne. Jest to zresztą typowe dla krajów „starej Unii”, podczas gdy w większości nowych państw członkowskich przeważają opłaty tego typu.

\section{Podsumowanie}

1. Oba główne wskaźniki charakteryzujące rozmiary opodatkowania ekologicznego, tj. wielkości środków z podatków ekologicznych wyrażone jako procent dochodów podatkowych ogółem oraz ich relacja do PKB, dla Polski sa zbliżone do średniej unijnej. Natomiast udział podatków transportowych jest

\footnotetext{
${ }^{7}$ Wynosi on 20 banów za sztukę, tj. niecałe 20 groszy.
} 
stosunkowo niski - „kosztem” podatków energetycznych - w porównaniu z większością krajów Unii Europejskiej.

2. Przeważająca część z podatków związanych ze środowiskiem, które obowiązuja w Polsce, występuje w analizowanych krajach (Dania, Estonia, Rumunia). Niekiedy są stosowane pewne, oryginalne rozwiązania podatkowe. $\mathrm{Na}$ przykład w Estonii obowiązują opłaty od rybołówstwa, a w Rumunii - specjalny podatek od importu samochodów czy ekopodatek od toreb na zakupy z materiałów nieodnawialnych.

3. W Estonii i Rumunii dominuja - podobnie jak w Polsce - opłaty ekologiczne. W krajach tych funkcjonują specjalne instytucje zbliżone do polskich funduszy ochrony środowiska i gospodarki wodnej, które gromadzą środki z opłat ekologicznych z przeznaczeniem na działania proekologiczne.

4. Niektóre proekologiczne rozwiązania podatkowe stosowane w Polsce nie znalazły się na liście podatków związanych ze środowiskiem przyjętej przez GUS na potrzeby sprawozdawczości Eurostatu. Tymczasem występują one w sprawozdawczości niektórych porównywanych krajów.

5. System podatków ekologicznych obowiązujących w Polsce, mimo jego pozytywnej ogólnej oceny, wymaga pewnych modyfikacji. Ewentualnie dotyczy to zarówno poszerzenia listy podatków na potrzeby sprawozdawczości statystycznej, jak i wprowadzenia pewnych sprawdzonych rozwiązań z innych krajów Unii Europejskiej.

\section{Literatura}

Air emissions and environmental taxes accounts. Final Report. Grant Agreement No 50904.2010.004-2010.590, 2013, Statistics Estonia, Tallin.

Bartniczak B., Ptak M., 2011, Optaty i podatki ekologiczne. Teoria i praktyka, Wydawnictwo Uniwersytetu Ekonomicznego we Wrocławiu, Wrocław.

Environmental Accounts. Final Report. Grant agreement for an action - no. 50904.2010.0042010.595, 2013, National Institute of Statistics of Romania, Bucharest.

Environmental tax statistics, http:/ / ec.europa.eu/eurostat/statistics-explained/index.php/ Environmental_tax_statistics (data wejścia: 10.08.2015).

Environmental taxes. A statistical guide. 2013 Edition, 2013, Eurostat/European Union.

Europejskie rachunki ekonomiczne środowiska: Moduł podatków środowiskowych. Końcowy raport techniczny z. diqatan zrealizowanych w ramach umowy o dotacje nr 50904.2011.005-2011.301. Okeres kwalifikowany od 1 stycznia 2012 roku do 31 grudnia 2013 roku, 2013, Główny Urząd Statystyczny Rzeczypospolitej Polskiej, Departament Badań Regionalnych i Środowiska, Warszawa.

Introduction of NACE, rev. 2 in the Danish Accounts for Environmental Taxes and Subsidies, 2012, Statistics Denmark.

Małecki P. P. (w druku) Gtówne elementy metodyczne procesu praygotowywania danych sprawozdawczych z zakeresu podatków zwiazanych ze środowiskiem w swietle nowych regulacji prawnych Unii Europejskiej, Folia Oeconomica, Acta Universitatis Lodziensis, Łódź. 
Małecki P. P., 2012, System opłat i podatków ekologicznych w Polsce na tle rozwiazań w krajach OECD, Wydawnictwo Uniwersytetu Ekonomicznego w Krakowie, Kraków.

Rozporzqdzenie Parlamentu Europejskiego i Rady (UE) nr 691/2011 z.dnia 6 lipca 2011 roku w sprawie europejskich rachunków ekonomicznych środowiska, Dz.U. L 192 z 22.7.2011.

Taxation trends in the European Union. Data for the EU Member States and Norway, 2009, Eurostat, Luxembourg. 